\title{
On the Edge in Rural Canada: The Changing Capacity and Role of the Voluntary Sector
}

\author{
Laura Ryser \& Greg Halseth \\ University of Northern British Columbia
}

\begin{abstract}
Since the 1980s, neoliberal policies have downsized or closed rural and small-town services. In response, voluntary groups have played an increasing role to retain basic supports. How voluntary groups are impacted, and how they react, will affect community development. Drawing upon our research across northern $\mathrm{BC}$ and Canada, this article explores the changing role of voluntary groups, with a focus on the structural and institutional barriers impeding their renewal. Our research suggests that voluntary organizations have been diversifying their human and financial capital, expanding partnerships, and developing smart infrastructure to enhance their capacity. More place-based policies and programs are needed to: renew relationships; create synergies; stabilize operations; renew mandates and procedures; develop training supports; enhance development expertise; build diversity, capacity, and support for volunteers; and develop information management systems.

\section{RÉSUMÉ}

Depuis les années 80 , des politiques néolibérales ont entraîné la diminution ou l'élimination de divers services dans les communautés rurales. En conséquence, les groupes bénévoles ont joué un rôle grandissant dans la préservation de services de base. Le traitement des bénévoles et leurs réactions face à ce traitement ont ainsi un impact sur le développement communautaire. Cet article a recours à notre recherche dans le nord de la Colombie-Britannique et ailleurs au Canada pour explorer le rôle changeant des groupes bénévoles dans un contexte où des défis structurels et institutionnels peuvent nuire à leur renouveau. Notre recherche laisse entendre que, pour accroître leurs capacités, les organisations bénévoles sont en train de diversifier leur capital humain et financier, augmenter le nombre de leurs partenariats et développer une infrastructure intelligente. II faut davantage de politiques et programmes qui tiennent compte du milieu afin de : renouveler les relations; créer des synergies; stabiliser les opérations; reformuler les mandats et procédures; appuyer les activités de formation; accroître l'expertise en développement; augmenter l'aide aux bénévoles ainsi que leur diversité et leurs capacités; et développer de meilleurs systèmes de gestion de l'information.
\end{abstract}

KEYWORDS / MOTS CLÉS : Rural; Restructuring; Voluntary sector; Institutional barriers; Innovation / Rural; Restructuration; Secteur bénévole; Obstacles institutionnels; Innovation 


\section{Ryser \& Halseth (2014)}

\section{INTRODUCTION}

Local service provision in rural areas and small towns has always faced the challenges of small population numbers and large distances between settlements. While these challenges were somewhat mitigated during a period of proactive public policy and Keynesian economic reforms following World War Two, since 1980, the application of neoliberal policy and neoclassical economic modelling has resulted in the widespread downsizing and closure of rural and small-town services (Markey, Halseth, \& Manson, 2012). Such services, however, are vital to supporting both community and economic transformation and renewal (Williamson, Beattie, \& Osborne, 2004). In response, service providers and nonprofit groups have engaged in voluntary work in order to retain some basic service supports. At the same time, economic and social restructuring has changed the environment within which voluntary groups work. If we are to understand the impacts of rural restructuring, we must also understand and address the needs of the voluntary sector. How voluntary groups are impacted, and how they react, will affect the ways in which community development plays out in rural and small town Canada.

Drawing on almost 15 years of research across northern British Columbia (B.C.) and Canada, this article explores the changing capacity and role of the voluntary sector in rural areas and small towns. The purpose of this review is to highlight thematic directions and opportunities for the Canadian rural voluntary sector, and to connect them with trends in other industrialized countries. This article includes three sections. The first introduces background on the state of rural areas and small towns in the new rural economy. The second looks at some specific barriers to renewing the rural voluntary sector. Finally, it concludes with a discussion of lessons learned and innovative approaches being adopted to renew the rural voluntary sector.

\section{THE NEW RURAL ECONOMY}

The new rural economy continues to evolve within a constantly shifting global economy. This global economy is about diversity, speed, and change. The increasingly hyper-connected global economy means that attention to community development and community economic development is needed on an ongoing basis. As such, rural areas and small towns must pay increasing attention to their place-based assets, and to how developing those assets for local benefit correspond with local aspirations (McDonald, Brown, Frost, Van Dijk, \& Rainnie, 2013). The emergence of an increasingly fast-paced global economy, and the subsequent transformations affecting the new rural economy, are also set against a wider backdrop of change in public policy support. Since the early 1980s, public policies adopted in many developed countries that are part of the Organization for Economic Cooperation and Development (OECD), have increasingly called for "bottom-up" community development (Argent, 2011; Shortall \& Warner, 2010). This transition-often associated with the adoption of neoliberal policy approaches-also fits well with the desires of many rural and small-town regions to have a larger say in community and regional development (Young \& Matthews, 2007). To be effective, however, this transformation in public policy supports and bottom-up renewal rests on continued synergy between the two. Bottom-up community and economic development ideas need the support of public policy in order to be realized (Markey et al., 2012). Unfortunately, while public policy has countenanced increasing bottom-up aspirations, it has concomitantly and systematically removed basic supports in terms of services and associated skills of former public sector workers (Markey, Harketh, \& Manson, 2007). The out-migration of professional and government employees from the service sector to regionalized centres, for example, has led to a loss of quality-of-life amenities and imposed burdens on those least able to afford the additional costs of travelling to access regionalized supports. It is clear that a robust foundation of quality-of-life amenities and services is necessary for both the recruitment and retention of people in a community as well as the stimulation of economic activity (Ryser \& Halseth, 2010). 


\section{Ryser \& Halseth (2014)}

\section{The role of the voluntary sector in the new rural economy}

It is within this transforming rural landscape that we examine the continuing importance of the voluntary sector. In terms of contemporary community development, research in Canada, England, and Scandinavia has demonstrated that without the voluntary sector, many services would not exist (Andersen \& Svensson, 2013; Hanlon, Rosenberg, \& Clasby, 2011; Lie \& Baines, 2007). The voluntary sector also plays a crucial role in helping communities cope with the impacts of demographic change and in promoting economic renewal (Lockie, Franettovich, Petkova-Timmer, Rolfe, \& Ivanova, 2009; Skinner \& Joseph, 2011; Steinerowski \& SteinerowskaStreb, 2012). It is often at the heart of local relationships and partnerships and plays a role in nurturing both leadership and trust (Sarros, Cooper, \& Santora, 2011).

Through social cohesion and social capital, voluntary sector organizations are able to mobilize, increase, and bridge various other types of capital to obtain a wider range of resources and information to build community capacity (Emery \& Flora, 2006). Voluntary organizations can create routine opportunities for interaction that, over time, can nurture "well-worn" pathways by which residents get things accomplished. By providing routine opportunities for interaction, voluntary organizations can build both experience and trust, which, in turn, become a solid foundation for innovative community capacity building. While there are lots of ways to define innovation (Osborne, 2002), it is generally understood as the adoption of something new. This could be a new idea; new knowledge, products, services, administrative practices, technology, strategies, processes, or behaviours; or new ways of doing things (Sarros, Cooper, \& Santora, 2011). These pathways can also lead to the creation of new organizations, new leaders in the community, or new solutions to entrenched problems. The key is that innovation must be implemented and it must be accepted as a new norm in the organization. Together, efforts through the voluntary sector can help enhance local quality-of-life and reduce out-migration.

\section{What makes "rural" unique}

In considering issues important to the voluntary sector, it is vital to understand that organizations in rural areas and small towns operate in a very different context than similar types of organizations in an urban setting. Distance and small population numbers-the basic underpinnings of rural areas and small towns-are key to these differences. To start, distance is a considerable challenge. There is distance involved in connecting with governmental agencies or key policy makers, which may determine the fate of voluntary sector groups and/or their funding applications. Distance exacerbates the possibility that policy makers do not understand small places. The opportunity to connect with wider networks of organizations or with government ministries and regionalized supports is also negatively impacted by both social distances-which are created through increasingly lengthy bureaucratic processes and accountability procedures-and the physical distances within which rural voluntary groups operate (McKinney \& Kahn, 2004; Molnar, Duffy, Claxton, \& Bailey, 2001). Distance also impacts exposure as well as access to information and different types of innovation, ideas, options, and solutions. With limited external networks, voluntary groups can become isolated and introverted, thereby limiting their capacity for renewal (Wollebæk, 2009). Rural and small town organizations know that a significant portion of their annual operating budget may be consumed by travel costs-either to deliver services in a low-density wide-reaching geographic area, or to connect with regionalized policy and program offices (Harris, Cairns, \& Hutchison, 2004).

In addition to the general challenges posed by a low-density rural or small town setting, the voluntary sector is also under stress from changes occurring within those contexts. One set of challenges comes from population decline. Over time, many of the industries that have been the foundation for rural and small town economies have been under economic threat from low-cost suppliers around the world (Hayter, 2000). To meet that challenge, Canadian resource industries have aggressively pursued efficiency as a means of lowering their 


\section{Ryser \& Halseth (2014)}

production costs in order to remain globally competitive (Edenhoffer \& Hayter, 2013). This often means a substitution of capital for labour, resulting in much smaller workforces. We are currently producing far more raw material for export with far less labour than at any time in our history. Population decline, brought about by diminishing employment opportunities, impacts not only the mean level of human capital within the community, but also the limited base from which groups can draw volunteers. This limits organizational capacity, and can also limit innovation and flexibility.

In addition to population decline, the remaining population is often aging (Davies, 2011). This trend is both attributed to the out-migration of younger families and the presence of an older workforce that is aging in place. As identified by Neil Hanlon and Greg Halseth (2005) this process of "resource frontier aging" can limit the community's capacity to sustain ongoing initiatives. These issues exacerbate the longstanding challenge of leadership renewal for voluntary groups in rural areas and small towns (Skinner \& Joseph, 2011). By definition, small places have small populations, which means that if leaders move on from their position or burn out from the stress of service delivery, there are relatively few potential volunteers to draw from.

Further, an increasing level of downloading, or the outright closure of public and private sector services, has exacerbated all of these issues (Halseth \& Ryser, 2006b). In a context where private and public sector services or supports have been downsized or eliminated, the voluntary and nonprofit sector has been increasingly called upon to fill the gap (Baines \& Cunningham, 2011; Hanlon et al., 2007). Not only does this increase the workload, but it increases the risk of burnout. And, as mentioned, the possibility of renewing voluntary participation is limited by small community size.

\section{BARRIERS TO RENEWING THE RURAL VOLUNTARY SECTOR}

Through our research, we have identified seven key issues that are impeding the renewal of the rural voluntary sector. In this section, we briefly review these barriers as a preface to discussing some innovative responses to the renewal challenge.

\section{Attitudinal barriers}

One key barrier to renewal involves the attitudes and actions of leaders. One of the central issues concerns the readiness for change in voluntary organizations. This includes recognition about the need for change, as well as the ability to ensure that there is the capacity to implement that change (Allen, Smith, \& Da Silva, 2013). At times, however, issues can arise around organizational protectionism, the entrenchment of positions (either policy positions or executive positions), unrealistic expectations (McKinney \& Kahn, 2004), or a more general reticence to accept change (Sobels, Curtis, \& Lockie, 2001).

\section{Operational barriers}

The operation of voluntary organizations can also be a barrier to renewal. This includes a lack of ongoing attention to renewing organizational roles, mandates, policies, procedures, and tools (Osborne, 1998). Very often we find organizations were created to address a need, but then continue on in a similar mandated role even after the need has changed, transformed, or disappeared. Without a clear vision, there may be conflicts about what the organization does, and why (Sorrentino \& Simonetta, 2011). For example, conflict can emerge within organizations that have a mixture of paid and voluntary workers due to different priorities about where to allocate resources, as well as different preferences for formal versus informal work and management practices (Kreutzer \& Jäger, 2011). Conflict can also emerge within organizations that have both paid and volunteer workers if paid staff are doing tasks that volunteers do for free. This can render unclear the roles and responsibilities of those in the organization, and in any partner organizations as well. When organizational roles 


\section{Ryser \& Halseth (2014)}

are not renewed, there can be a loss of relevance and a decline of volunteer assistance (Bruce, Jordan, \& Halseth, 1999). When voluntary sector groups take over services previously delivered by the public or private sector, there can be difficulty managing expectations (McKinney \& Kahn, 2004). There may also be a lack of planning for projected demands or the rapid pace at which new service demands arise (Barr, Brock, Brownlee, Frankel, Hall, Murray, Nicol, Roach, Rowe, \& Scott, 2006). While such organizational barriers are not unique to rural organizations, these challenges can exacerbate pressures and undermine the effectiveness of an already limited capacity in underserviced small communities (Cloke, Milbourne, \& Widdowfiled, 2000; Hanlon, Halseth, \& Ostry, 2011; Johnsen, Cloke, \& May, 2005; O'Connell, 2003). With limited human, financial, infrastructural, and political capital, rural voluntary organizations must ensure that their capacities are not wasted, but are purposefully deployed through their operational structures in the most relevant and effective way.

Heightened competition for the increasingly small "pot" of government funding programs (Allen et al., 2013; Graddy \& Morgan, 2006; Walk, Schinnenburg, \& Handy, 2013) means that groups and organizations may not work together on applications that would benefit everyone, but may only seek to secure the funding that would allow their organization to continue. In addition to drifting mandates as voluntary and nonprofit organizations chase available funds (which can generate internal conflict), this can also create conflict across communities as different groups move from a cooperative to a competitive environment.

\section{Communication barriers}

Another set of barriers around renewal involves communication. On a day-to-day basis, the increasingly large workload of voluntary groups with limited human resources due to small populations, means that communication within and across organizations can become disrupted and infrequent. This can lead to miscommunication and misunderstandings. In addition, while voluntary groups have started to use a wider range of communications tools (Halseth \& Ryser, 2006a), there still remain generational differences in the types of communications tools that people use (Ryser \& Halseth, 2013b). Small rural voluntary organizations have been less likely to use social media and other Internet-based tools to strengthen networks with others inside and outside of the community (Burt \& Taylor, 2000; Eimhjellen, Wollebæk, \& Strømsnes, 2013). This has been exacerbated by the limited broadband infrastructure and technical support staff in small and, especially, remote communities (Grimes, 2003; McKeown, Noce, \& Czerny, 2007). In looking to recruit younger people into voluntary groups, more attention must be paid to communication media. This includes the transition from predominantly face-to-face and telephone communication to using the Internet and social media-based communication to support and strengthen interpersonal, virtual, other forms of interaction (Eimhjellen, 2013).

\section{Financial barriers}

Financial resources are, of course, a significant barrier to voluntary sector renewal. Not only are there fewer grant programs (Imagine Canada, 2010), but many of those funding programs have outdated frameworks or misunderstand rural realities and operating costs (Halseth \& Ryser, 2010). This decrease in funding has also been exacerbated by the retrenchment of industry and business support since the recession of 2008 (Peddle, 2011; Ryser, Rajput, Halseth, \& Markey, 2012a). Government funding has also been increasingly delivered on a short-term basis, thereby limiting the ability of voluntary groups to secure stable resources for staff (Walk et al., 2013). These funding realities-coupled with the decline in donations and community fundraising that come with the burnout of a limited voluntary sector base-all create challenges for maintaining services and renewing both the mandates and operational structure of voluntary groups. Research in the U.K. also suggests that rural voluntary organizations that have obtained external grants have been viewed as "cash rich" in comparison to to other local organizations, and have been at risk of losing other sources of in-kind and financial funding (McKinney \& Kahn, 2004). 


\section{Ryser \& Halseth (2014)}

\section{Limited human resources}

Building upon these earlier barriers, another significant challenge to renewal involves human resources. To start, rural voluntary groups can have a limited administrative capacity (Poole, Ferguson, DiNitto, \& Schwab, 2002). They may be able to draw upon-but not necessarily have continuous access to-high-order financial or management skills. At the same time, however, most training and capacity building supports are concentrated in metropolitan or urban settings, and it is difficult for rural groups to access such supports (Halseth \& Ryser, 2006b). There is often a lack of skills to develop proposals suited to the increasingly complex world of grant applications (Nothwehr, Erickson, \& Schultz, 2012; Simpson \& Clifton, 2010), as well as a lack of time to create the onerous and lengthy applications or reports now required for program funding (these groups are, after all, busy delivering more and more services or supports). Often, a failure to succeed with funding applications can breed non-participation in the future. When groups are busy organizing every day for the delivery of services, or chasing dollars to keep those services going, there is often little time left for the succession planning or job shadowing needed to help build and renew collective capacity (Byron, Curtis, \& Lockwood, 2001). In addition, there is often little time left at the end of the day for the "heavy lifting" work that goes into building collaborative partnerships within and across communities (Packer, Spence, \& Beare, 2002; Ryser \& Halseth, 2013a).

In some regions, the voluntary and nonprofit sector is just not able to compete with the wages offered in the resource sector (Ryser, Markey, Manson, \& Schwamborn, \& Halseth, forthcoming). This challenge is exacerbated by industries that are making use of transient workforces-workforces that can generate additional pressures on community services. Long distance labour commuting, an increasingly common feature of the rural landscape, further diminishes the volunteer base available in these small communities. As residents engage in long distance labour commuting, their engagement with voluntary organizations in their home community may become random, infrequent, and noncommittal (Wollebæk \& Selle, 2004), thereby impacting the ability of voluntary groups to strengthen local social cohesion and social capital across residents.

\section{Infrastructure barriers}

Aging or limited communication, social, and transportation infrastructure can also be a barrier to renewal (Grimes, 2003, 2000; Skinner, 2008). This can include the age or absence of computers, printers, and other information access technologies (McKinney \& Kahn, 2004). The donation of outdated computing equipment does nothing to help an organization access information online when all of that online information (e.g., application forms) requires the most up-to-date operating systems, a high-speed connection, and large RAM in order to download efficiently and properly. There is also limited access to technical supports; transportation options beyond personal vehicles; and even services such as daycare (on an ongoing or temporary basis), which can help to facilitate participation in meetings and engagements (Snavely \& Tracy, 2000; Torgerson \& Edwards, 2012). In addition, accessing space within communities for meetings, operations, and program delivery, as well as equipment and material storage, can be a problem.

\section{Policy barriers}

The final barrier to renewal involves policy. Policy has not kept pace with the changing realities of rural areas and small towns (Leipert, Kloseck, McWilliam, Forbes, Kothari, \& Oudshoorn, 2007; Walsh, O'Shea, Scharf, \& Murray, 2012). Instead, policy has been pressured to reduce the level of risk to central governments rather than to provide a more supportive policy environment for the voluntary sector operating on the ground. For example, there are increasingly complex policies, rules, and regulations around liability, insurance, maintenance of facilities or services, and training and qualifications of individuals (Lie \& Baines, 2007). While no one argues that these topics need attention, public policy often directly downloads the responsibility for satisfying these policy needs to the voluntary group, rather than creating a cooperative environment for resolving these challenges. Such requirements do not reflect or support the more limited human and financial capacity of rural voluntary 


\section{Ryser \& Halseth (2014)}

groups, and, therefore, only exacerbate the operational pressures for these organizations. These challenges can be compounded by the distance involved in connecting with insurance providers, government agencies, or key policy makers in distant centres (Harris et al., 2004). This distance also exacerbates the possibility that policy makers do not understand the needs or constraints of rural voluntary organizations-to the point where policies and programs become ineffective in supporting their on-the-ground operations (Molnar et al., 2001).

A second area of policy challenge concerns transformations in expectations around the operations of rural voluntary groups. Research in the U.S., Australia, and Europe demonstrates that the movement toward more standardized and professional services (Graddy \& Morgan, 2006; Kreutzer \& Jäger, 2011; McDonald \& Warburton, 2003) and integrated or shared models of service delivery (Poole et al., 2002), as well as the movement to a more business-oriented model of service delivery (Lie \& Baines, 2007), are challenging the transformative capacity of these organizations. Again, the transitions occurring in the wider society are one thing, but the notion that public policy expects the voluntary sector to bear the burden of these transformations without adequate support and assistance is, however, quite another matter. As Keith Snavely and Martin Tracy (2000) argue, government funding agencies continue to require separate allocation, budgeting, reporting, and evaluation processes that are not conducive to nurturing collaborative relationships across the voluntary sector.

\section{APPROACHES TO INNOVATION AND RENEWAL}

With a continued emphasis on challenges facing the voluntary sector, few have explored renewal within the voluntary sector, and even fewer have situated these challenges within the unique rural context. Through our work, a number of lessons have been identified as these organizations work to renew themselves across a very diverse rural landscape (Cloke et al., 2000; Hanlon et al., 2011; Hanlon \& Halseth, 2005; Lockie et al., 2009). Irrespective of the context, small communities are building capacity through the voluntary sector in a number of ways. In this section, we focus our attention on how they are diversifying their human and financial capital, as well as how they are using partnerships and smart infrastructure to overcome the barriers identified earlier and support ongoing operations and organizational renewal.

\section{Human capital}

To start, the rural voluntary sector is building its human capital by using a range of recruiting strategies. This has included using print media, the Internet, community presentations, job postings, volunteer databases, and informal methods such as word of mouth (Halseth \& Ryser, 2006a). Voluntary organizations are also working with other service providers, such as schools and healthcare providers, to adopt joint recruitment campaigns (Walk et al., 2013). In the rural context, it has not just been about using a range of recruiting strategies, but also about organizations being more flexible in terms of the types of volunteers and commitments they are seeking. This has been especially important during times of significant industrial restructuring, where job losses may have prompted much of the local labour force to commute long distances for work (Lockie et al., 2009; McDonald, Mayes, \& Pini, 2012; Sandow \& Westin, 2010). Resources, such as volunteer fire departments and search and rescue teams, often require volunteers to regularly attend training exercises. Our research indicated that this is not always possible with rotating shift schedules and out-of-town work (Ryser et al., 2012a). In response, voluntary groups have been very supportive and flexible in finding ways for these workers to continue their training and engagement in the community. Some, for example, were able to maintain their training with mine rescue crews at distant industrial work sites.

Voluntary organizations have also been expanding the geographic scale of their operations. While many voluntary organizations have typically operated at a community level in the past, research in Canada and Norway has tracked organizations that have scaled-up to recruit and engage members on a regional level 


\section{Ryser \& Halseth (2014)}

(Beckie, Kennedy, \& Wittman, 2012; Halseth \& Ryser, 2006a; Wollebæk \& Selle, 2004). This broader geographic scale can assist voluntary groups in drawing upon a broader network and range of resources.

Some groups have offered paid positions or compensation for items such as supplies or fuel, which can be a significant cost in rural regions due to large distances and low densities. Research that we conducted also suggested that organizations with paid or compensated leaders or board members were less likely to face a lack of new leadership, decreased member participation, and volunteer burnout (Halseth \& Ryser, 2007).

Some communities have developed a family-friendly certification program-which has been adopted by voluntary groups as well as other public and private sector groups-to recruit new members, volunteers, and staff (Ryser, Schwamborn, \& Halseth, 2012b). The goal of this program is to support flexible scheduling, access to childcare, organizing family-friendly activities, and other things. Similar to other places, small communities have also been looking at ways to provide volunteer rewards and incentives. This can range from passes to the recreation centre to donations for community groups (Ryser \& Halseth, 2013b). Training and professional development have also been used as incentives to recruit and retain volunteers (Walk et al., 2013). In some cases, nonprofits have worked to build the capacity of their clients. In Kitimat, British Columbia, for example, one community service group has worked with their clients to operate a local food share program that redistributes outdated food from local grocery stores to those in need (Ryser \& Halseth, 2013b). They have trained their clients in data entry and creating spreadsheets to support the operations of this and other programs. This not only equips their clients with the skills they will need to engage in the workforce, it also provides the organization with more human resources.

Having stable and adequate human resources can really impact the resiliency of an organization. Diverse human resources, for example, provide stability for developing and maintaining funding and partnerships (McDonald \& Warburton, 2003; Milbourne, Macrae, \& Maquire, 2003). Diversifying through gender, economic sectors, and age groups has been important, as each of these groups bring different networks and resources that organizations can draw upon (Halseth \& Ryser, 2007). Some organizations, for example, have used their networks to expand their human resources by subcontracting or sharing staff to perform administrative and financial management tasks (Poole et al., 2002). Diverse networks also enhance the visibility of an organization, as well as support throughout the community for its initiatives.

\section{Financial resources}

Through our research, we found that many rural voluntary organizations are also diversifying their funding sources. More voluntary groups, for example, are obtaining or sharing the services of a grant writer (Ryser et al., 2012b). In some cases, this has been supported with funding from local governments and regional trusts. Voluntary organizations are also pursuing a broader range of funding and in-kind resources from government, industry, business, trusts, nonprofits, and other sources. They are also relying more on revenue from services and membership fees. An important component of this includes revenues from social enterprises. The development of social enterprises in rural communities is still largely emerging, but there have been some important role models (Ryser \& Halseth, 2012). Obtaining stable staff and board members is, of course, not just important for supporting daily activities but also for procuring funding. In fact, having a board of directors was a condition many voluntary groups had to meet in order to obtain funding from government agencies. Our work with the New Rural Economy Project demonstrated that voluntary organizations equipped with a board of directors were more likely to receive funding from federal, provincial, and municipal governments (Halseth \& Ryser, 2006a). This largely reflects the importance of adopting accountability measures in order to secure government funding. 


\section{Ryser \& Halseth (2014)}

\section{Partnerships}

As voluntary groups work to build capacity, partnerships are increasing, particularly with groups in other places. These partnerships can lead to new ways to deliver supports. They are also becoming increasingly important to obtain funding (Bradford, 2003; O'Toole \& Burdess, 2004). Through partnerships, voluntary organizations can enhance the legitimacy of their activities and demonstrate that their organization's activities have a wider appeal and support across the community (Milewa, Dowswell, \& Harrison, 2002). Partnerships are also increasingly important to provide supports to vulnerable groups that are complex and often beyond the capacity or mandate of any individual organization (Cloke et al., 2000)-something that is particularly important in smaller communities that have fewer specialized supports.

Research conducted in four Canadian provinces demonstrated that partnerships in rural places have been used to link voluntary groups to other networks, expertise, and resources (Halseth \& Ryser, 2007). The use of outside expertise and expanded networks demonstrates the importance of building and bridging social capital in order to improve service delivery. Through partnerships, groups expanded their networks to update each other on activities, promote services, and offer referrals. Expertise was obtained through advice, information sharing, and joint decision-making. The business community, for example, has provided advice about investing money earned from donations or publications. Finally, voluntary groups used partnerships to expand their resources to better provide programs, share staff, obtain access to office space or equipment, and to meet a host of other needs. Furthermore, in some communities, the local government is providing support by taking care of the administration of contracts for some voluntary and nonprofit groups that have part-time staff (Ryser \& Halseth, 2013b).

Our research in northern BC also explored how voluntary groups have been working to build the capacity of their partners (Ryser \& Halseth, 2013b). This has been particularly important when they have engaged with Aboriginal groups, where the key to renewing relationships and capacity was flexibility-in terms of how they worked together and in terms of encouraging Aboriginal partners to make the rules that would guide the collaboration. Groups with partnerships have also used a range of communication tools to connect with partners both in their community and outside of it. It is important to note, however, that while rural voluntary organizations are using a range of communication tools, face-to-face contact remains important because it allows people to pick up on non-verbal cues such as body language, and to spend more time getting to know their partners. Furthermore, voluntary groups in rural areas have been working to collaborate with local government and align their messages for when they engage with senior government stakeholders and industry leaders (Ryser et al., 2012b). They are also working to find projects that will be of interest to industry (e.g., water conservation, recreation, health), in order to enhance their relevance.

\section{Smart infrastructure}

Rural and small town voluntary groups are paying particular attention to smart infrastructure to provide and maintain supports that might not otherwise exist. In some cases, the local government, churches, mall management, restaurants, and other private sector groups have provided free or low-cost access to space for voluntary organizations to meet or deliver services (Ryser \& Halseth, 2013b). For example, churches in small communities provide space for food banks and similar operations. This has been important, of course, in communities that are struggling with temporary or permanent industry closures, but also in booming resource communities where commercial vacancies are low and commercial rental costs are rising. While some groups are sharing space, other groups are either sharing client information, budgets, and staff and administrative resources (Snavely \& Tracy, 2000).

There is an urgent need for new models of rural service infrastructure to support the long-term sustainability of rural voluntary organizations in constrained fiscal environments. More organizations in both developed and 


\section{Ryser \& Halseth (2014)}

developing countries are addressing these challenges by co-locating or by developing multipurpose facilities in smaller communities in order to cultivate synergies, collaborate, and enhance communication across service providers (Johns, Kilpatrick, \& Whelan, 2007; Moseley, Parker, \& Wragg, 2004). Not only can this provide a more efficient portal for residents to access information about needed supports, it can also allow groups to share facility operating costs.

\section{PULLING IT ALL TOGETHER: AN ILLUSTRATIVE EXAMPLE}

Recent initiatives in Port Clements, B.C., demonstrate how rural voluntary organizations can work with other local and provincial stakeholders to diversify their human and financial capital, and use partnerships and smart infrastructure to overcome barriers. Port Clements is a community that experienced a significant decline in the forest sector and, subsequently, the local population. With a limited tax base, it was also challenged to replace aging infrastructure, such as the community hall and the elementary school. At the same time, an aging population was creating the need for a seniors' centre. This prompted the local government to form a partnership with the school district and the regional library system to build a multiplex building (Ministry of Education, 2007). Opened in 2008, the multiplex building consists of a new municipal hall, a community gym, an elementary school, a daycare, the public library, and multipurpose rooms that accommodate a community kitchen and a seniors' drop-in. Not only are more organizations sharing the costs of the facility and its operations and maintenance, but as a brand-new building, it has very low energy and operating costs.

\section{LOOKING FORWARD}

Looking forward, some important reflections must be considered to support the renewal of the voluntary sector and to better position it to engage in the new rural economy. First, it is important to recognize that the increasingly rapid boom and bust cycles in many rural economies can introduce a number of factors that shape change in the rural voluntary sector. Second, the unique experience of "rural" extends beyond cyclical economies and fluctuating populations, and includes the loss of institutional memory, constantly changing capacities, distance to policy writers and other decision makers, and limited infrastructure. In this discussion, we suggest six key areas that need attention in order to enhance the capacity and resiliency of the rural voluntary sector.

To respond to these challenges, rural voluntary groups need to establish a stable structural framework. This includes a careful investment of time and resources to renew their mandate, roles, policies, procedures, and tools in order to remain relevant in constantly changing environments. Voluntary groups also need to pay attention to diversity in their membership, leadership, and board of directors: attention to gender, being inclusive of different age groups, and incorporating people who have connections with different sectors of the community. Such diversity is key to developing resiliency by providing diverse networks from which to attract new members, as well as access to a wider range of resources and expertise. As groups work to enhance organizational stability, strategies should be deployed to take advantage of untapped expertise and energy within the community. These untapped resources can range from youth to seniors to tradespeople working in industry. To strengthen their foundation and stability, small community organizations need to make sure that adequate supports are in place to encourage broad participation by paying attention to the provision of childcare and transportation services. Rural voluntary organizations also need to purposefully invest in the renewal of relationships with stakeholders both within their communities and beyond.

Another element of an organization's stability concerns the capacity of its human resources. There is a need to invest in volunteer training to equip people with the tools to do what is needed. In small communities, this may also involve connecting with other voluntary groups to pursue joint or collaborative training exercises in order to 


\section{Ryser \& Halseth (2014)}

reduce costs. Local governments or community organizations may also invest in a volunteer coordinator in order to help build the capacity of volunteer resources. Voluntary groups also need to encourage and support the development and training of a board of directors in areas such as strategic and financial planning. Through investments in social capital, groups also need to transfer skills among those engaged in voluntary work. This ensures that if out-migration occurs, the collective capacity remains within the organization (Winterton, Warburton, Clune, \& Martin, 2013). Again, it is about developing the next generation of rural leaders.

Once adequate human resources are in place, rural voluntary groups must make sure they are effectively using communication tools to improve relations locally and beyond. This will require voluntary groups to engage routine communication with stakeholders, in order to understand the opportunities and challenges that may lie ahead. A broad range of communication tools are needed to connect with different residents and stakeholders, as not everyone communicates or understands information in the same way. While there is a growing trend to use social media and the Internet to strengthen the integration of volunteers and partnerships and to improve the efficiency of sharing information (Eimhjellen, 2013), personal communication remains very important in small communities. Voluntary groups must also invest in building better information management systems to reflect today's fast-paced, connected environment, and to be ready to engage with-and meet the information requirements of-industry and government leaders (Burt \& Taylor, 2000; Poole et al., 2002). It is about strategically using communication tools to invest in renewing relationships, as well as to build synergies, partnerships, and collaborations across groups in order to use resources and expertise more efficiently.

Voluntary organizations must also consider the integration of smart service infrastructure in order to create greater economic efficiencies and get away from older models of delivering services. Voluntary groups can become very focused on their current needs. Through long-term planning and thinking strategically about creative community foundations, voluntary groups can work to reduce future costs. Smart service infrastructure can enhance the capacity of these groups to be inclusive, connected, and accessible as they engage in their day-to-day operations.

Policy and program levers developed by senior levels of government, funding agencies, and affiliated organizations can play an important role in supporting the renewal of the voluntary sector. Voluntary groups have benefitted from the need to complete strategic planning processes and to formalize the training of board members and volunteers in order to renew community leadership and capacity (Graddy \& Morgan, 2006). In an era of service restructuring, program designs should facilitate collaboration both locally and at the regional level. Senior levels of government can also encourage and strengthen collaboration and partnerships within the rural voluntary sector by developing strategic policies, incentives, and long-term supports that reflect the unique context of rural regions, as well as by developing multi-organizational grant allocation and management processes (Snavely \& Tracey, 2000). Policy and program levers should also provide support for rural voluntary organizations to invest adequate time and resources in human capacity, and in organizational structural tools to strengthen operations during the early phases of initiatives (Poole et al., 2002). There is also a need for common sense funding programs, applications, and reporting procedures that are streamlined in order to help voluntary groups use their time wisely and focus their energy and resources where they are needed most (Barr et al., 2006). At the local government level, tax breaks have been provided to businesses and organizations that have donated space to voluntary organizations; thereby functioning as "incubator facilities" for the voluntary sector (Bruce et al., 1999).

Finally, we need to increase the "visibility" of the opportunities and challenges associated with the rural voluntary sector in national policy debates. This goes beyond talking about small communities as places of crisis. Their diversity and unique circumstances-distance to regionalized supports and policy makers, aging 


\section{Ryser \& Halseth (2014)}

infrastructure, and potentially limited technical infrastructure-require a different set of approaches and supports to renew the rural voluntary sector.

\section{ACKNOWLEDGEMENTS}

We greatly appreciate the advice provided by the editor and referees to support the completion of this manuscript. This research reflects the generous support provided through a number of grants, including the Social Sciences and Humanities Research Council (SSHRC) Initiative on the New Economy grant 512-20021003, the SSHRC Insight Development grant 430-2011-0475, the United Way of Northern British Columbia, and the Canada Research Chair in Rural and Small Town Studies 950-222604.

\section{REFERENCES}

Allen, S., Smith, J., \& Da Silva, N. (2013). Leadership style in relation to organizational change and organizational creativity: Perceptions from non-profit organizational members. Nonprofit Management \& Leadership, 24(1), 23-41.

Andersen, A., \& Svensson, T. (2013). Internet-based mental health services in Norway and Sweden: Characteristics and consequences. Administration and Policy in Mental Health and Mental Health Services Research, 40(2), 145-153.

Argent, N. (2011). Trouble in paradise? Governing Australia's multifunctional rural landscapes. Australian Geographer, 42(2), 183-205.

Baines, D., \& Cunningham, I. (2011). "White knuckle care work": Violence, gender and new public management in the voluntary sector. Work, Employment, \& Society, 25(4), 760-776.

Barr, C., Brock, K., Brownlee, B., Frankel, S., Hall, M., Murray, V., Nicol, R., Roach, R., Rowe, P., \& Scott, K. (2006). Strengthening the capacity of non-profit and voluntary organizations to serve Canadians: Recommendations based on the national survey of non-profit and voluntary organizations. Toronto, ON: Knowledge Development Centre, Imagine Canada.

Beckie, M., Kennedy, E., \& Wittman, H. (2012). Scaling up alternative food networks: Farmers' markets and the role of clustering in western Canada. Agriculture and Human Values, 29(3), 333-345.

Bradford, N. (2003). Public-private partnership? Shifting paradigms of economic governance in Ontario. Canadian Journal of Political Science, 36(5), 1005-1033.

Bruce, D., Jordan, P., \& Halseth, G. (1999). The role of voluntary organizations in rural Canada: Impacts of changing availability of operational and program funding. Montreal, QC: New Rural Economy Project, Concordia University.

Burt, E., \& Taylor, J. (2000). Information and communication technologies: Reshaping voluntary organizations? Nonprofit Management \& Leadership, 11(2), 131-143.

Byron, I., Curtis, A., \& Lockwood, M. (2001). Exploring burnout in Australia's Landcare Program: A case study in the Shepparton Region. Society \& Natural Resources, 14(10), 901-910.

Cloke, P., Milbourne, P., \& Widdowfield, R. (2000). Partnership and policy networks in rural local governance: Homelessness in Taunton. Public Administration, 78(1), 111-133.

Davies, A. (2011). On constructing ageing rural populations: "Capturing" the grey nomad. Journal of Rural Studies, 27(2), 191-199.

Edenhoffer, K., \& Hayter, R. (2013). Organizational restructuring in British Columbia's forest industries 19802010: The survival of a dinosaur. Applied Geography, 40, 222-231.

Eimhjellen, I. (2013). Internet communication: Does it strengthen local voluntary organizations? Nonprofit and Voluntary Sector Quarterly, Online First, 1-20. 


\section{Ryser \& Halseth (2014)}

Eimhjellen, I., Wollebæk, D., \& Strømsnes, K. (2013). Associations online: Barriers for using web-based communication in voluntary associations. Voluntas, Online First, 1-24.

Emery, M., \& Flora, C. (2006). Spiraling up: Mapping community transformation with community capitals framework. Community Development, 37(1), 19-35.

Graddy, E., \& Morgan, D. (2006). Community foundations, organizational strategy, and public policy. Nonprofit and Voluntary Sector Quarterly, 35(4), 605-630.

Grimes, S. (2003). The digital economy challenge facing peripheral rural areas. Progress in Human Geography, 27(2), 174-193.

Grimes, S. (2000). Rural areas in the information society: Diminishing distance or increasing learning capacity. Journal of Rural Studies, 16(1), 13-21.

Halseth, G., \& Ryser, L. (2010). A primer for understanding issues around rural poverty. CDI Publication Series. Prince George, BC: Community Development Institute, University of Northern BC.

Halseth, G., \& Ryser, L. (2007). The deployment of partnerships by the voluntary sector to address service needs in rural and small town Canada. Voluntas, 18(3), 241-265.

Halseth, G., \& Ryser, L. (2006a). Innovative services and voluntary organizations: Project report. Montreal, QC: Initiatives on the New Economy, Concordia University.

Halseth, G., \& Ryser, L. (2006b). Trends in service delivery: Examples from rural and small town Canada, 1998-2005. Journal of Rural and Community Development, 1(2), 69-90.

Hanlon, N., \& Halseth, G. (2005). The greying of resource communities in northern British Columbia: Implications for health care delivery in already underserviced communities. The Canadian Geographer 49(1), 1-24.

Hanlon, N., Halseth, G., \& Ostry, A. (2011). Stealth voluntarism: An expectation of health professional work in underserviced areas? Health \& Place, 17(1), 42-49.

Hanlon, N., Rosenberg, M., \& Clasby, R. (2007). Offloading social care responsibilities: Recent experiences of local voluntary organizations in a remote urban centre in British Columbia, Canada. Health and Social Care in the Community, 15(4), 343-351.

Harris, M., Cairns, B., \& Hutchinson, R. (2004). "So many tiers, so many agendas, so many pots of money": The challenge of English regionalization for voluntary and community organizations. Social Policy \& Administration, 38(5), 525-540.

Hayter, R. (2000). Flexible crossroads: The restructuring of British Columbia's forest economy. Vancouver, BC: UBC Press.

Imagine Canada. (2010). A framework for action for the non-profit sector. Toronto, ON: Imagine Canada.

Johns, S., Kilpatrick, S., \& Whelan, J. (2007). Our health in our hands: Building effective community partnerships for rural health service provision. Rural Society, 17(1), 50-65.

Johnsen, S., Cloke, P., \& May, J. (2005). Transitory spaces of care: serving the homeless people on the street. Health and Place, 11(4), 323-336.

Kreutzer, K., \& Jäger, U. (2011). Volunteering versus managerialism: Conflict over organizational identity in voluntary associations. Nonprofit and Voluntary Sector Quarterly, 40(4), 634-661.

Leipert, B., Kloseck, M., McWilliam, C., Forbes, D., Kothari, A., \& Oudshoorn, A. (2007). Fitting a round peg into a square hole: Exploring issues, challenges, and strategies for solutions in rural home care settings. Journal of Rural Nursing and Health Care, 7(2), 5-20.

Lie, M., \& Baines, S. (2007). Making sense of organizational change: Voices of older volunteers. Voluntas, 18(3), 225-240.

Lockie, S., Franettovich, M., Petkova-Timmer, V., Rolfe, J., \& Ivanova, G. (2009). Coal mining and the resource community cycle: A longitudinal assessment of the social impacts of the Coppabella coal mine. Environmental Impact Assessment Review, 29, 330-339. 


\section{Ryser \& Halseth (2014)}

Markey, S., Halseth, G., \& Manson, D. (2012). Investing in place: Economic renewal in northern British Columbia. Vancouver, BC: UBC Press.

Markey, S., Halseth, G., \& Manson, D. (2007). The (dis)connected North: Persistent regionalism in northern British Columbia. Canadian Journal of Regional Science, 30(1), 57-78.

McDonald, C., Brown, A., Frost, L., Van Dijk, P., \& Rainnie, A. (2013). Partnerships and integrated responses to rural decline: The role of collective efficacy and political capital in Northwest Tasmania, Australia. Journal of Rural Studies, 32, 346-356.

McDonald, P., Mayes, R., \& Pini, B. (2012). A spatially-oriented approach to the impact of the Ravensthorpe nickel mine closure in remote Australia. Journal of Industrial Relations, 54(1), 22-40.

McDonald, C., \& Warburton, J. (2003). Stability and change in nonprofit organizations: The volunteer contribution. Voluntas, 14(4), 381-399.

McKeown, L., Noce, A., \& Czerny, P. (2007). Factors associated with Internet use: Does rurality matter? Rural and Small Town Canada Analysis Bulletin, 7(3), 1-15. Catalogue no. 21-006-XIE.

McKinney, R., \& Kahn, H. (2004). Lottery funding and changing organizational identity in the UK voluntary sector. Voluntas, 15(1), 1-19.

Milbourne, L., Macrae, S., \& Maquire, M. (2003). Collaborative solutions or new policy problems: Exploring multi-agency partnerships in education and health work. Journal of Education Policy, 18(1), 19-35.

Milewa, T., Dowswell, G., \& Harrison, S. (2002). Partnerships, power, and the "new" politics of community participation in British health care. Social Policy \& Administration, 36(7), 796-809.

Ministry of Education. (2007). New facility to benefit students and community. Press release. Victoria, BC: Ministry of Education, Province of British Columbia.

Molnar, J., Duffy, P., Claxton, L., \& Bailey, C. (2001). Private food assistance in a small metropolitan area: Urban resources and rural needs. Journal of Sociology and Social Welfare, 28(3), 187-209.

Moseley, M., Parker, G., \& Wragg, A. (2004). Multi-service outlets in rural England: The co-location of disparate services. Planning, Practice, \& Research, 19(4), 375-391.

Nothwehr, F., Erickson, L., \& Schultz, U. (2012). Rural public health systems: A view from lowa. In R. Crosby, M. Vendel, R. Vanderpool, \& B. Casey (Eds.), Rural populations and health: Determinants, disparities, and solutions (pp. 151-167). San Francisco, CA: John Wiley \& Sons, Inc.

O'Connell, M. (2003). Responding to homelessness: An overview of US and UK policy interventions. Journal of Community and Applied Social Psychology, 13(2), 158-170.

Osborne, S. (2002). Voluntary organizations and innovation in public services. New York, NY: Routledge.

Osborne, S. (1998). Organizational structure and innovation in U.K. voluntary social welfare organizations: Applying the Aston measure. Voluntas, 9(4), 345-362.

O'Toole, K., \& Burdess, N. (2004). New community governance in small rural towns: The Australian experience. Journal of Rural Studies, 20, 433-443.

Packer, J., Spence, R., \& Beare, E. (2002). Building community partnerships: An Australian case study of sustainable community-based rural programmes. Community Development Journal, 37(4), 316-326.

Peddle, C. (2011). The impact of the 2008 recession on youth sport programs in a local community. Unpublished masters thesis. Windsor, ON: University of Windsor.

Poole, D., Ferguson, M., DiNitto, D., \& Schwab, A. (2002). The capacity of community-based organizations to lead local innovations in welfare reform: Early findings from Texas. Nonprofit Management and Leadership, 12(3), 261-276.

Ryser, L., \& Halseth, G. (2013a). So you're thinking about a retirement industry: Economic and community development lessons from resource towns in northern British Columbia. Community Development, 44(1), 83-96.

Ryser, L., \& Halseth, G. (2013b). Tracking the social and economic transformation process in Kitimat, BC. Prince George, BC: UNBC Community Development Institute. 


\section{Ryser \& Halseth (2014)}

Ryser, L., \& Halseth, G. (2012). Challenges for engaging social economy businesses in rural and small town renewal. In L. Mook, J. Quarter, \& S. Ryan (Eds.), Businesses with a difference: Balancing the social and the economic (pp. 161-181). Toronto, ON: University of Toronto Press.

Ryser, L., \& Halseth, G. (2010). Rural economic development: A review of the literature from industrialized economies. Geography Compass, 4(6), 510-531.

Ryser, L., Markey, S., Manson, D., Schwamborn, J., \& Halseth, G. (forthcoming). From boom and bust to regional waves: Development patterns in the Peace River Region, British Columbia. Journal of Rural and Community Development.

Ryser, L., Rajput, A., Halseth, G., \& Markey, S. (2012a). Hollowing out the community: Community impacts of extended long distance labour commuting. Prince George, BC: UNBC Community Development Institute. URL: http://www.unbc.ca/sites/default/files/assets/community_development_institute/research/ maccommute/hollowing_out_the_community_summary_report_july_2012.pdf [June 6, 2013].

Ryser, L., Schwamborn, J., \& Halseth, G. (2012b). Lessons from economic upswings: A case study of the Peace River Region. Prince George, BC: UNBC Community Development Institute. URL: http://www.unbc.ca/sites/default/files/assets/community_development_institute/research/ktids/ktids_su mmary_theme_report_copy1.pdf [June 6, 2013].

Sandow, E., \& Westin, K. (2010). The persevering commuter: Duration of long distance commuting. Transportation Research A, 44(6), 433-445.

Sarros, J., Cooper, B., \& Santora, J. (2011). Leadership vision, organizational culture, and support for innovation in not-for-profit and for-profit organizations. Leadership and Organization Development Journal, 32(3), 291-309.

Shortall, S., \& Warner, M. (2010). Social inclusion or market competitiveness? A comparison of rural development policies in the European Union and the United States. Social Policy \& Administration, 44(5), 575-597.

Simpson, G., \& Clifton, J. (2010). Funding and facilitation: Implications of changing government policy for the future of voluntary Landcare groups in Western Australia. Australian Geographer, 41(3), 403-423.

Skinner, M. (2008). Voluntarism and long-term care in the countryside: The paradox of a threadbare sector. The Canadian Geographer, 52(2), 188-203.

Skinner, M., \& Joseph, A. (2011). Placing voluntarism within evolving spaces of care in ageing rural communities. GeoJournal, 76, 151-162.

Snavely, K., \& Tracy, M. (2000). Collaboration among rural non-profit organizations. Nonprofit Management and Leadership, 11(2), 145-165.

Sobels, J., Curtis, A., \& Lockie, S. (2001). The role of Landcare group networks in rural Australia: Exploring the contribution of social capital. Journal of Rural Studies, 17(3), 265-276.

Sorrentino, M., \& Simonetta, M. (2011). Assessing local partnerships: An organisational perspective. Transforming Government: People, Process, \& Policy, 5(3), 207-224.

Steinerowski, A., \& Steinerowska-Streb, I. (2012). Can social enterprise contribute to creating sustainable rural communities? Using the lens of structuration theory to analyse the emergence of rural social enterprise. Local Economy, 27(2), 167-182.

Torgerson, M., \& Edwards, M. (2012). Demographic determinants of perceived barriers to community involvement: Examining rural / urban differences. Nonprofit and Voluntary Sector Quarterly, 42(2), 371-390.

Walk, M., Schinnenburg, H., \& Handy, F. (2013). Missing in action: Strategic human resource management in German nonprofits. Voluntas, Online First, 1-31.

Walsh, K., O'Shea, E., Scharf, T., \& Murray, M. (2012). Ageing in changing community contexts: Cross-border perspectives from rural Ireland and Northern Ireland. Journal of Rural Studies, 28(4), 347-357.

Williamson, A., Beattie, R., \& Osborne, S. (2004). Addressing fragmentation and social exclusion through community involvement in rural regeneration partnerships: Evidence from the Northern Ireland experience. Policy \& Politics, 32(3), 351-369. 
Winterton, R., Warburton, J., Clune, S., \& Martin, J. (2013). Building community and organizational capacity to enable social participation for ageing Australian rural populations: A resource-based perspective. Ageing International, Online First, 1-17.

Wollebæk, D. (2009). Survival in local voluntary association. Nonprofit Management \& Leadership, 19(3), 267-284.

Wollebæk, D., \& Selle, P. (2004). The role of women in the transformation of the organizational society in Norway. Nonprofit and Voluntary Sector Quarterly, 33(3), 120S-144S.

Young, N., \& Matthews, R. (2007). Resource economies and neoliberal experimentation: The reform of industry and community in rural British Columbia. Area, 39(2), 38-51.

\section{ABOUT THE AUTHORS / LES AUTEURS}

Laura Ryser ${ }^{*}$ is Research Manager, Rural and Small Town Studies, University of Northern British Columbia, Prince George, BC. Email: ryser@unbc.ca .

Greg Halseth is Canada Research Chair, Rural and Small Town Studies, Geography Program, University of Northern British Columbia, Prince George, BC. Email: halseth@unbc.ca .

${ }^{*}$ Corresponding author 